\title{
Study of Ground Water Recharge in the District of Nadia and Murshidabad for Estimating the Stage of Ground Water Development
}

\author{
Uddipta Ghosh* and Ranajit Kumar Biswas \\ Department of Soil and Water Engineering, Bidhan Chandra Krishi Viswavidyalaya, \\ Mohanpur, Nadia, West Bengal-741252, India \\ *Corresponding author
}

\section{A B S T R A C T}

\section{Keywords}

Ground water recharges, Utilizable ground water resources, Ground water draft, Ground water development, Over exploited zone

Article Info

Accepted: 15 January 2018 Available Online: 10 February 2018
The ground water recharge of Nadia and Murshidabad districts of the state of West Bengal were estimated and compared to withdrawal of it for the purpose of different sectarian use viz. agriculture, industrial and domestic. It was evaluated that the utilizable annual ground water resources of Nadia and Murshidabad district were 590.75 MCM and 769.25 MCM respectively and also found that the net annual ground water draft of Nadia and Murshidabad were 1157.1 MCM and 1405.6 MCM respectively. So it has been clearly found that the district of Nadia and Murshidabad were affected of over exploitation of ground water to the extent of 566.35 MCM and 636.35 MCM respectively. The stage of groundwater development of Nadia and Murshidabad were found $195.87 \%$ and $182.72 \%$ respectively, i.e. more than $100 \%$ which also indicated the area as an overexploited zone. The districts are also noted for cultivation of high water requiring boro rice. Either the boro cultivation area needs to be reduced or artificial ground water recharge need to be encouraged. Immediate measures are required to reduce the ground water use or to increase the ground water recharge to have a balance between use and availability and to protect the areas against the possible environmental disaster.

\section{Introduction}

Water has been one of the essential requirements of the world for all times. That is why we find most of the civilizations on or near the bank of rivers only. But now in modern world all needs for drinking, food production and for industrial uses cannot be fulfilled by only open sources of water. As many cities now days are far apart from the rivers or lakes, they are left with no other option other than ground water, therefore a major part of which is fulfilled by groundwater. Recent studies tell that $37 \%$ of all lands around the world equipped for irrigation are served by ground water. So this source of water is getting depleted day by day as forest area is reducing, stress on agricultural land, industrial development and population is increasing. In the last two decades, for instance, the groundwater irrigated areas in India increased by $105 \%$, whereas the surfacewater irrigated areas rose by only $28 \%$ (IWMI, 2001). But the indiscriminate use of this vital natural resource has resulted fast falling of groundwater table in many parts of India. It 
has been reported that about 79 Administrative Blocks in the State in 8 different districts (Malda, Murshidabad, Nadia, North 24 Praganas, South 24 Praganas, Howrah, Hooghly, and Bardhaman) are severely affected due to drinking of water contaminated with arsenic $(>0.05 \mathrm{mg} / \mathrm{L})$ which is much higher than the WHO permissible limit of 0.01 $\mathrm{mg} / \mathrm{L}$ (Govt. of India, Planning Commission Yojona, July, 2007). With the above in view the present study was undertaken to evaluate the ground water recharge of Nadia and Murshidabad district for estimating the stage of ground water development and also find out the safe exploitation of ground water.

\section{Study area description}

District Nadia is agriculture based district and is located in the heart of West Bengal. The entire district lies in the rich alluvial zone of the Ganga and its tributaries. The district is bounded on the North and North-west by the district of Murshidabad. The area lies between $22^{\circ} 53^{\prime}$ and $24^{0} 11^{\prime}$ north latitude and between $88^{0}$ 09' and $88^{\circ} \quad 48^{\prime}$ east longitude. Total geographical area of the district is 3,927 sqkms. Nadia district has a large agriculture area. Out of total 373414 ha area, about 85733 ha is not available for agriculture which is 23 percent of the total land of the district. The average temperature ranges from $37.6^{\circ} \mathrm{C}$ to $25.4^{\circ} \mathrm{C}$ during summer months and between $23.7^{\circ}$ Celsius to $8.5^{\circ}$ Celsius during winter months. Murshidabad district is situated between the latitudes $24^{0} 50^{\prime} 20^{\prime \prime}$ and $23^{\circ}$ $43^{\prime} 30^{\prime \prime}$ in the Northern Hemisphere. The eastern most proximity of the district is marked by $88^{0} 46^{\prime} 00^{\prime \prime}$ east longitude and its western most extremity by $87^{\circ} 49^{\prime} 17^{\prime \prime}$ east longitude. Average rainfall of the district is Average rainfall $1400 \mathrm{~mm}$. The Maximum temperature of summer is $38.6^{0} \mathrm{C} \&$ Minimum temperature is $7.8^{0}$. Total geographical area is 532.5 ha out of which 399.01 ha is cultivable area

\section{Materials and Methods}

As per recommendation of Ground Water Estimation Committee (1984) two methods were used to estimate the ground water recharge, namely ground water level fluctuation method and rainfall infiltration method.

\section{Ground water level fluctuation method}

The recharge was computed using the following formula as per 1984 methodology

$\mathrm{R}^{\mathrm{wtf}}=\mathrm{h} \times \mathrm{S}_{\mathrm{y}} \times \mathrm{A}$ Where $\mathrm{R}=$ Recharge of ground water during monsoon in $\mathrm{MCM}, \mathrm{h}=$ Rise in water level in $\mathrm{m}$ in monsoon, $\mathrm{S}_{\mathrm{y}}=$ Specific yield value of the formation and $\mathrm{A}=$ Area occupied by the formation in sq.km. While computing the area (A), the areas where the slope is more than $20 \%$ were excluded. Then the recharge figures were obtained for each block. Average water table fluctuation of Nadia and Murshidabad were 2.47 and 2.81 metre (Source: Central Ground Water Board).Specific yield values of Nadia and Murshidabad were taken as 0.11 because both districts were belong alluvium zone. Total recharge area of Nadia and Murshidabad were 3927 and 5324 sq.km respectively (Anonymous, 2014).

\section{Rainfall infiltration method}

Subsequently the ground water recharge by rainfall infiltration method also was calculated for the monsoon period. Rainfall infiltration factor recommended by the Committee was mostly used. Recharge assessment based on rainfall infiltration factor is calculated using the formula of $R^{\text {rif }}=f \times A \times$ Normal rainfall in monsoon season. Where $\mathrm{f}=$ rainfall infiltration factor, $\mathrm{A}=$ Area occupied by the formation in sq.km. Rainfall infiltration factor was taken as 0.10 for both districts as they were belong from the same hydro geological 
zone. The average rainfall data (1996-2005) of two districts were collected from the Department of Agricultural Meteorology and Physics, B.C.K.V., Nadia. Average rainfall of Nadia and Murshidabad were 1474 and 1417 $\mathrm{mm}$ respectively.

\section{Compared using percent deviation}

Recharge figures computed using the two methodologies were compared as below

Percent Deviation $=100 \times\left(\mathrm{R}^{\mathrm{wtf}}-\mathrm{R}^{\mathrm{rif}}\right) / \mathrm{R}^{\mathrm{rif}}$

The rainfall recharge for normal monsoon season rainfall was finally adopted as per criteria. If P.D is greater than or equal to $20 \%$, and less than or equal to $+20 \%$, actual recharge was taken as the value estimated by the water table fluctuation method. If P.D was less than $-20 \%$, actual recharge was taken as equal to 0.8 times the value estimated by the rainfall infiltration factor method. If P.D is greater than $+20 \%$, actual recharge was taken as equal to 1.2 times the value estimated by the rainfall infiltration factor method.

\section{Estimation of stage of groundwater development}

The groundwater assessment unit was categorized into different categories as safe, semi critical, critical and overexploited based on groundwater resources available and groundwater draft.

The various categories are: safe - groundwater development is <70\%; semi critical groundwater development is $70-90 \%$; critical - groundwater development is $90-100 \%$; overexploited-groundwater development is $>100 \%$. The stage of groundwater development was calculated using the formula: [(Annual Net Ground Water Draft) /
(Annual Utilizable Ground Water Resources)] x 100 .

\section{Total ground water draft}

\section{Nadia}

Ground water draft for irrigation use $-15.69 \mathrm{x}$ $10^{8} \mathrm{~m}^{3}$

Ground water draft for domestic and industrial use $-0.84 \times 10^{8} \mathrm{~m}^{3}$

Total Annual gross ground water draft $16.53 \times 10^{8} \mathrm{~m}^{3}$

\section{Murshidabad}

Ground water draft for irrigation use $-19.19 \mathrm{x}$ $10^{8} \mathrm{~m}^{3}$

Ground water draft for domestic and industrial use $-0.89 \times 10^{8} \mathrm{~m}^{3}$

Total Annual gross ground water draft -20.08 $\times 10^{8} \mathrm{~m}^{3}$

(Source: State Water Investigation Directorate, Kolkata, West Bengal).

The net annual groundwater draft was estimated at $70 \%$ of the gross annual draft as recommended by GEC. As per GEC norms, annual utilizable groundwater resources were taken as $85 \%$ of total annual groundwater resources.

\section{Results and Discussion}

The study was conducted for information of ground water recharge and to compare the deficit of ground water with respect to draft of the respective district. The result have been showed in Table 1. 
Table.1 Estimation stage of groundwater development

\begin{tabular}{|c|c|c|c|c|c|c|c|}
\hline District & $\begin{array}{c}\mathrm{R}^{\mathrm{wit}} \times 10^{8} \\
\mathrm{~m}^{3}\end{array}$ & $\begin{array}{l}\mathrm{R}^{\mathrm{rif}} \\
\mathbf{x} 0^{8} \\
\mathrm{~m}^{3}\end{array}$ & $\begin{array}{c}\text { Percent } \\
\text { Deviation }\end{array}$ & $\begin{array}{c}\text { Actual } \\
\text { Recharge } \\
\mathbf{x} 10^{8} \mathrm{~m}^{3}\end{array}$ & $\begin{array}{l}\text { Net utilizable } \\
\text { groundwater } \\
\text { resources } x 10^{8} \mathrm{~m}^{3}\end{array}$ & $\begin{array}{l}\text { Net Annual } \\
\text { Ground Water } \\
\text { Draft } \times 10^{8} \mathrm{~m}^{3}\end{array}$ & $\begin{array}{l}\text { Deficit } \\
\times 10^{8} \mathrm{~m}^{3}\end{array}$ \\
\hline & 10.67 & 5.79 & & 6.95 & 5.9025 & 11.571 & 5.66 \\
\hline Murshidabad & 16.46 & 7.54 & 118.30 & 9.05 & 7.69 & 14.056 & 6.36 \\
\hline
\end{tabular}

Use to meet up water requirement for different sectors i.e. agriculture, industry and domestic. The method suggested by Ground Water Estimation Committee (GEC,1984) (1884) was used to estimate the ground water recharge. It was found that that the utilizable annual ground water resources of Nadia and Murshidabad district were 590.25 MCM and 769.25 MCM respectively and also found that the net annual ground water draft of Nadia and Murshidabad were 1157.1 MCM and 1405.6 MCM respectively. So it has been clearly found that the district of Nadia and Murshidabad were affected of over exploitation of ground water to the extent of 566.35 MCM and 636.35 MCM respectively.

\section{Estimation Stage of Groundwater Development Nadia}

$(11.57 / 5.9025) \times 100=195.87 \%$

Murshidabad : $(14.056 / 7.69) \times 100=182.7 \%$

The stage of groundwater development of Nadia and Murshidabad were found $195.87 \%$ and $182.7 \%$ respectively, i.e. more than $100 \%$ which also indicates the area as an overexploited zone. If other sources of recharge were taken into consideration then the amount of total recharge could have increased by some amount decreasing the ratio as represented by stage of groundwater development.

In reviewing the present ground water status in Nadia and Murshidabad districts, it may be stated that unless the ground water use is reduced immediately otherwise there are great chance of environmental disaster. The districts which are found withdrawing excess ground water are also noted for cultivation of high water requiring boro rice. Either the boro cultivation area needs to be reduced or artificial ground water recharge need to be encouraged. Also the methods of water harvesting technology should be taken immediately to enhance the level of ground water artificially.

\section{References}

Anonymous, 2014. http://www.wbagrimarketingboard.gov.i n/Area/Geographical.html

GEC, 1984. Groundwater Resource Estimation Methodology-1984, Report of the Groundwater Estimation Committee, Ministry of Water Resources, Government of India.

International Water Management Institute. 2001. The strategic plan for IWMI 2000-2005. Colombo, Srilanka: International Water Management Institute.

\section{How to cite this article:}

Uddipta Ghosh and Ranajit Kumar Biswas. 2018. Study of Ground Water Recharge in the District of Nadia and Murshidabad for Estimating the Stage of Ground Water Development. Int.J.Curr.Microbiol.App.Sci. 7(02): 1467-1470. doi: https://doi.org/10.20546/ijcmas.2018.702.177 